\title{
High Molecular Sericin from Bombyx mori Cocoons: Extraction and Recovering by Ultrafiltration
}

\author{
Marcelino L. Gimenes, Vitor R. Silva, Melissa G. A. Vieira, Meuris G. C. Silva, and Agnes P. Scheer
}

\begin{abstract}
The present study focus on sericin extraction process from Bombyx mori cocoons using water in absence of chemical additives under different physical conditions aiming to obtain high molecular weight sericin. Separation and fractionation of sericin proteins to obtain high molecular weight material was also carried out using ultrafiltration process at different operating modes: batch, diafiltration and batch with back flushing water pulse. The molecular weight of extracted sericin protein using pure water showed in general a size distribution varying from 20 up to $400 \mathrm{kDa}$, with major peaks between $200 \mathrm{kDa}$ and $100 \mathrm{kDa}$ and peaks with fraction of sericin lower than $100 \mathrm{kDa}$, depending on conditions used in the extraction and concentration. The results demonstrated viability to separate sericin fractions having molecular size higher than $50 \mathrm{kDa}$, using the ultrafiltration process with $50 \mathrm{kDa}$ cut-off membrane, however, a flux decline above $90 \%$ was detected independent of operating mode. Increasing the concentration factor from 2 to 4 promotes the permeation of sericin molecules of high molecular weight, reducing the rejection coefficient of $71.1 \%$ to $60.4 \%$.
\end{abstract}

Index Terms - Sericin, extraction, ultrafiltration, fouling.

\section{INTRODUCTION}

Silk manufacturing is one of the textile industrial sector where the intensive water consumption cannot be avoid, therefore resulting in large volume of wastewater. In this manufacturing, the largest wastewater stage is the degumming process, which is used for elimination of external sericin prior to dyeing; generally synthetic soap solutions is used at $95^{\circ} \mathrm{C}$ for 1 hour. As expected, $100 \mathrm{~kg}$ of silk produces almost $22 \mathrm{~kg}$ of residual sericin in wastewater [1]-[3]. By traditional process, sericin shows partial hydrolysis, reduces its natural molecular weight and loses some functional properties [4], [5].

Sericin is a highly hydrophilic macromolecular protein, comprising of 18 amino acids, with predominant polar amino acid groups, as serine $(25 \%)$, acids aspartic $(17 \%)$, threonine $(6 \%)$ and acid glutamic (5\%) [3], [6], [7]. Due this natural composition, sericin can be applied in cosmetics formulations, including skin and hair care products. In food industry, sericin

Manuscript received September 5, 2013; revised December 7, 2013.

M. L. Gimenes is with the Department of Chemical Engineering, State University of Maringá, Colombo Av. 5970, Maringá, Brazil (e-mail: marcelino.gimenes@gmail.com).

V. R. Silva and A. P. Scheer are with the Graduate Program of Food Engineering, Federal University of Paraná, Francisco H. Santos St. s/n, Curitiba, Brazil (e-mail: vrenan@ufpr.br, agnesps@gmail.com).

M. G. A. Vieira and M. G. C. Silva are with the Department of Products and Processes Design, University of Campinas, Albert Einstein Av. 500, Campinas, Brazil (e-mail: melissagav@feq.unicamp.br, meuris@feq.unicamp.br). peptides showed functional properties to development of new products with antioxidant properties and metal ion-chelating activity [7], [8]

The recovered sericin with high molecular weight can be applied in many uses for biomaterial and biofilms development. In tissue engineering, sericin can be used to induce the oriented crystallization from biomaterials based in hidroxyapatites and improve their biocompatibility due the presence of polar groups [9], [10]. Biodegradable materials with high molecular weight sericin can developed, due the presence of the large amount of polar side chain made of hydroxyl, carboxyl and amino groups, that can be used to enable easy cross-linking, copolymerization or blending with other polymers [1], [11], [12].

The study of alternative degumming methods to remove sericin from cocoons, and the methods to recovery and recycling sericin by-products from degumming stage could be significant economic and social benefit. Conventional degumming process, with soap and alkalis is effective to remove sericin, but promote the hydrolysis of the sericin chain structure, losing potential properties, while the soap removal from sericin solution is hard and expensive [13]. Sericin extraction by urea with 2-mercaptoetahnol showed high efficiency, however, a cost-consuming step of dialysis is necessary to purify the sericin solution before sericin application [14], [15]. Enzymatic degumming can be effective to remove sericin from silk cocoon; however, it is an expensive process and promotes the specific proteolytic hydrolysis of the primary sericin chain structure, which causes a molecular weight reduction [5], [13].

Recovery of valuable raw materials from wastewater, as biological molecules, has been well studied by ultrafiltration. Fabiani et al. [16] applied Ultrafiltration with cut-off of 15-30 $\mathrm{kDa}$ in silk degumming wastewater, where $95 \%$ of rejection was reported for sericin volume concentrataion factor of 4 . However, a severe flux decline as high as $90 \%$ was observed. Capar et al. [2] earned the complete recovery of the fraction of sericin with high molecular weight $(180 \mathrm{KDa}-200 \mathrm{kDa})$ with polyethersulfone membrane of $20 \mathrm{kDa}$, but partial permeation was detected for fractions lower than $80 \mathrm{kDa}$ and high flux decline was detected on the order of $87.6 \%$.

The present study focused on sericin extraction process Bombyx mori cocoons using water, in absence of chemical additives under different temperatures. Also, the extracted sericin was submitted at ultrafiltration process to promote the fractionation of sericin protein in order to obtain retentate with high molecular weight.

\section{MATERIAL AND METHODS}

Sericin was extracted from cocoons of Bombyx mori 
silkworm provided from northwest region of Paraná, Brazil. The cocoons were cut into small pieces (about $1 \mathrm{~cm}^{2}$ ) and then immersed in extracted solution. For each assay; 7.5 grams of chopped cocoon were deposited in $250 \mathrm{~mL}$ of extract solution in a Erlenmeyer of $500 \mathrm{~mL}$. The extraction processes studied were hot water extraction and aqueous solution of $\mathrm{Na}_{2} \mathrm{CO}_{3}$ (Anhydrous $99.5 \%$, Vetec, Brazil) at $80{ }^{\circ} \mathrm{C}$ and $120{ }^{\circ} \mathrm{C}$. The extraction yield $E Y$ was evaluated by gravimetric method [17], by (1), where: $E Y$ is the extraction yield (\%), $M_{F}$ is the dried cocoon mass after the extraction $(\mathrm{g})$ and $M_{I}$ is the initial dried cocoon mass before the extraction $(\mathrm{g})$.

$$
E Y=\left[1-\frac{M_{F}}{M_{I}}\right] \cdot 100 \%
$$

Surface morphology of silk degummed, i.e. the insoluble silk fibroin, was examined with a scanning electron microscope (Jeol ${ }^{\mathrm{TM}}$, model JSM - 6360L, Japan) to observe the presence of sericin on the fibroin surface, after the extraction process.

The extracted solution with hot water process was treated in a ultrafiltration process (PAM Membranas ${ }^{\mathrm{TM}}$, Brazil) with hollow fiber membrane of polyethersulfone $(50 \mathrm{kDa}$ and surface area of $520 \mathrm{~cm}^{2}$ ). Ultrafiltration was carried out under standard operating conditions: Transmembrane pressure of $0.05 \mathrm{MPa}$, feed flow of $1.0 \mathrm{~L} / \mathrm{min}$ and initial sericin concentration of $3.0 \mathrm{~g} / \mathrm{L}$. The permeate flux was evaluated by gravimetric method [18], by (2), where: $J_{P}$ is the permeate flux $\left(\mathrm{kg} / \mathrm{m}^{2} \mathrm{~h}\right), M_{P}$ is permeate mass $(\mathrm{kg}), t$ is time (h) and $S$ is the membrane surface area $\left(\mathrm{m}^{2}\right)$.

$$
J_{P}=\frac{1}{S} \frac{d M_{P}}{d t}
$$

The ultrafiltration system was operated by batch mode, diafiltration mode and batch + backwashing water pulse. The batch mode operation was the process where the permeate flow was continuous removed from the system (Fig. 1a), while in the diafiltration mode the permeate flow was continuous removed and the system was fed with water at the same flow of the permeate removed (Fig. 1b).

The batch mode + black flushing operation is the same procedure of the batch mode, however, each interval of 15 minutes the process is interrupted and subjected to a pulse of backwash with water for 3 minutes (reverse flux, from permeate channel, across membrane and recycling to the system by retentate channel), at pressure of $0.1 \mathrm{MPa}$. The water is fed by permeate channel and recycled to feed tank by retentate channel (Fig. 1c).

The sericin concentration in permeate and retentate flows were determined by Bradford method [19]. The rejection coefficient $C R(\%)$ and concentration factor $C F$ were evaluated by (3) and (4), respectively, where: $C_{P}$ is the concentration of sericin in the permeate flow $(\mathrm{g} / \mathrm{L})$, and $C F$ is the sericin concentration in feed stream $(\mathrm{g} / \mathrm{L}) ; M o$ and $M_{F}$ are the initial and final mass solution $(\mathrm{kg})$ [18].

$$
C R=\left[1-\frac{C_{P}}{C_{F}}\right] \cdot 100
$$

$$
C F=\frac{M o}{M o-M_{P}}
$$
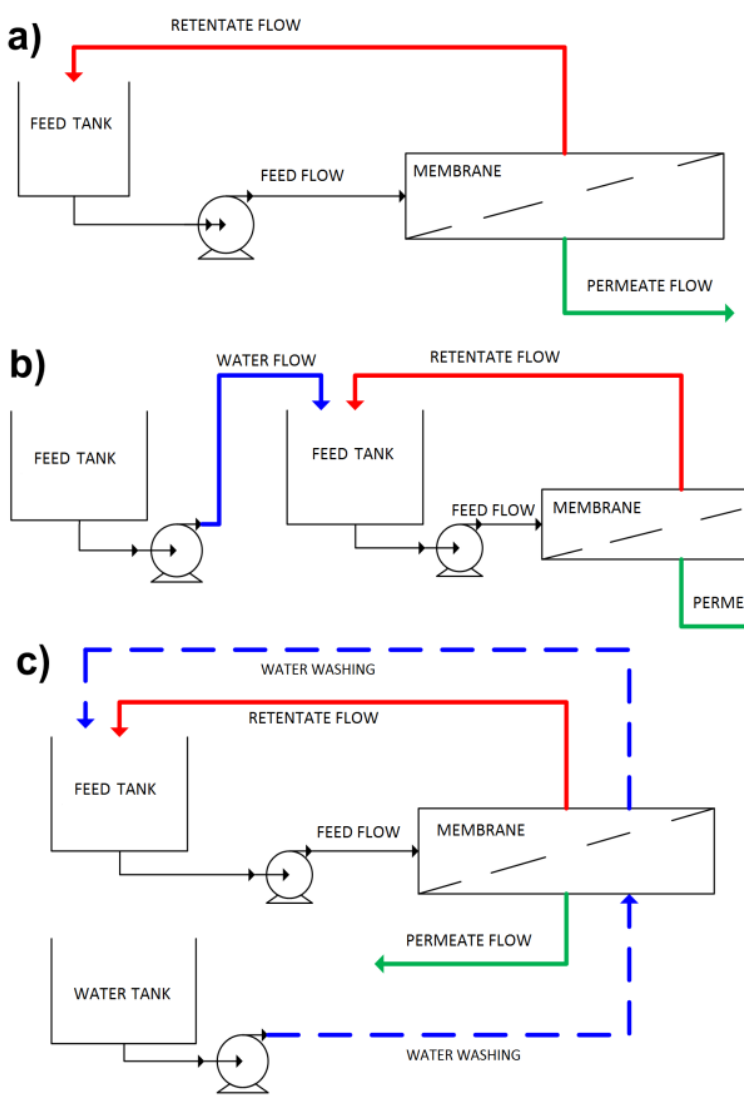

Fig. 1. Ultrafiltration modes operation. a) batch; b) diafiltration; c) batch + backflushing.

The fouling resistance effects were estimated using the resistance model [20], [21]. This model describes the effects that may interfere with the permeate flux as a function of the total resistance $R_{T}$. The permeate flux can be described as (5), where $\Delta \mathrm{P}$ is the transmembrane pressure, $\mu_{P E R M}$ is the permeate viscosity.

$$
R_{T}=\frac{\Delta P}{\mu_{P E R M} \cdot J_{P}}
$$

Fouling resistance $R_{F}$ is obtained by difference between the total resistance $R_{T}$ of sericin solution permeation and the hydraulic membrane resistance (6):

$$
R_{F}=R_{T}-R_{M}
$$

The hydraulic resistance $R_{M}$ was measured by (7) with deionized water, cleaning membrane at transmembrane pressure of $0.04 \mathrm{MPa}$ and water temperature of $30^{\circ} \mathrm{C}$, where $J_{W}$ is the water permeate flux through the cleaning membrane and $\mu_{W}$ is the water viscosity.

$$
R_{M}=\frac{\Delta P}{\mu_{W} \cdot J_{W}}
$$

The molecular weight distribution was measured with size exclusion chromatography HPLC Merck $^{\mathrm{TM}}$ Hitachi 
LaChrom, with quaternary pump L-7100, autosampler L-7250, refractor index detector L-7490 and a module of heater column L-3000). The standard molecular weight used was the Pululan polysaccharide, with the standard of molecular weight: $20 \mathrm{kDa}, 50 \mathrm{kDa}, 100 \mathrm{kDa}, 200 \mathrm{kDa}, 400$ $\mathrm{kDa}$ and $800 \mathrm{kDa}$.

All experiments were made in triplicate and the results were expressed in terms of means and standard deviations. The analysis of variance was then performed for the treatments. Tukey's test was used to compare means with 5\% significance level. The software Statistica 7.0 (Statsoft $^{\mathrm{TM}}$, USA) was used for statistical analysis.

\section{RESULTS AND DISCUSSION}

\section{A. Extraction Process}

The extraction yields of sericin are shown in Table I. Sericin extraction with water at $120{ }^{\circ} \mathrm{C}$ extraction was extraction yield of $21.99 \pm 0.96 \%$, while at temperature process lower than boiling point of water the extraction yield is insignificant. Extraction yields obtained in this study without chemical was the same that obtained by Haggag et al. [22] with enzymatic process of $21.8 \%$.

According with Padamwar et al. [23], sericin can be classified in three groups: Sericin A, (outermost layer in cocoon), Sericin B (middle layer in cocoon) and Sericin C (the innermost layer and adjacent protein). Each one has different properties (molecular weight, amino acids composition and protein secondary structure) and since the sericin $\mathrm{C}$ has a higher proportion of the beta-sheet structure than the other groups, it has a lower degree of solubility in water. As illustrated in Fig. 2b, the residual sericin present on the surface of the silk sericin is due to group $\mathrm{C}$, more strongly linked with the hydrophobic structure of fibroin.

High temperature decreases the hydrogen bonding stability, formed by the binding between the various hydroxyl groups, allowing the interaction of water with hydroxyl groups of the polar amino acid [24]. Due the predominant amount of hydrophobic amino acids in fibroin, only sericin is removed in water at high temperature.

Chemicals break all protein interactions, make easily the water permeation inside the protein and remove sericin, as showed in Fig. 1a. Extraction yield with aqueous solution of $\mathrm{Na}_{2} \mathrm{CO}_{3}$ at $120{ }^{\circ} \mathrm{C}$ showed the highest extraction yield of $30.04 \pm 0.83 \%$, consistent with the amount of sericin present in Bombyx mori cocoons, according with the literature [1], [14].

TABLE I: EXTRACTION YIELD OF SERICIN BY BOMBYX MORI COCOONS

\begin{tabular}{ccc}
\hline \hline Extraction process & $\begin{array}{c}\text { Temperature } \\
\left({ }^{\circ} \mathrm{C}\right)\end{array}$ & $\begin{array}{c}\text { Extraction yield } E Y \\
(\%)\end{array}$ \\
\hline $\begin{array}{c}\text { Hot water } \\
\text { Extraction with } \mathrm{Na}_{2} \mathrm{CO}_{3}\end{array}$ & 80 & $0.75 \pm 0.68^{\mathrm{D}}$ \\
$0.5 \%$ & 80 & $23.68 \pm 0.85^{\mathrm{B}}$ \\
Hot water & 120 & $21.99 \pm 0.96^{\mathrm{C}}$ \\
Extraction with $\mathrm{Na}_{2} \mathrm{CO}_{3}$ & 120 & $30.04 \pm 0.83^{\mathrm{A}}$ \\
\hline \hline
\end{tabular}

* means with different letters represent statistically difference according to the Tukey's test $(p<0.05)$

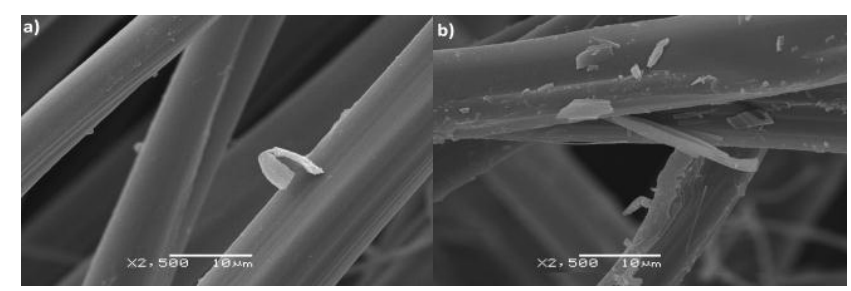

Fig. 2. Scanning Electronic Microscopy (SEM) of degummed cocoon, after the extraction process. a) Extraction with $\mathrm{Na}_{2} \mathrm{CO}_{3} 0.5 \%$ at $120^{\circ} \mathrm{C}$; b) water extraction at $120{ }^{\circ} \mathrm{C}$. Illustration of the residual sericin present on the surface of the silk sericin.

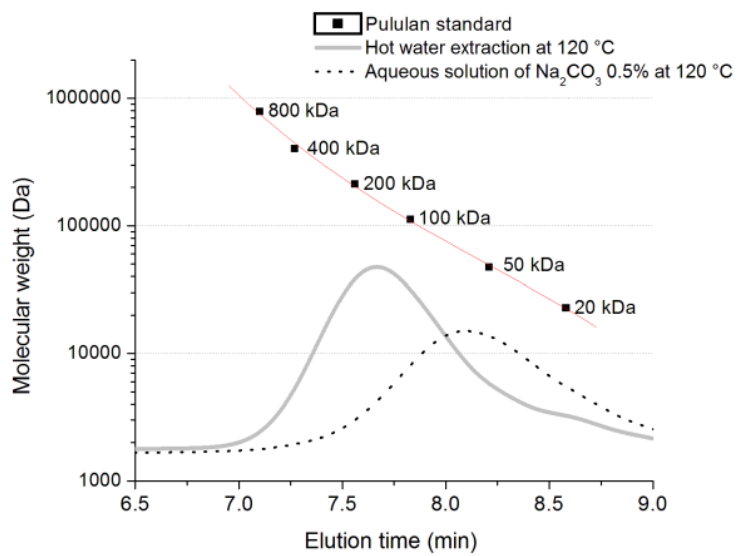

Fig. 3. Molecular weight profiles of sericin solution.

The molecular weight of extracted sericin protein using pure water showed in general a size distribution varying from 20 up to $400 \mathrm{kDa}$, with major peaks between $200 \mathrm{kDa}$ and 100 $\mathrm{kDa}$ and sericin fractions lower than $100 \mathrm{kDa}$, while the extraction with $\mathrm{Na}_{2} \mathrm{CO}_{3}$ showed molecular weight lower than $100 \mathrm{kDa}$ (Fig. 3). Thus, the extraction with chemical indicates further chemical hydrolysis of sericin, while the hot water extraction preserves the primary structure and composition, which enables its use in the development of biomaterials.

\section{B. Ultrafiltration Process}

Sericin solution obtained by extraction with water at $120{ }^{\circ} \mathrm{C}$ was treated in ultrafiltration process under the following conditions set: initial sericin concentration of 3.0 $\mathrm{g} / \mathrm{L}$, feed flow of $1.0 \mathrm{~L} / \mathrm{min}$ and transmembrane pressure of $0.05 \mathrm{MPa}$ (optimal transmembrane pressure and feed flow were determined in previous study developed by Silva et al. [25]).

The flow profile of permeate in all operating modes evaluated showed an abrupt initial decrease due to the formation of the polarization layer and, after 10 minutes of process, reached the equilibrium between the polarized layer and renewal surface effects. After the equilibrium between the renewal effects and the polarized layer, fouling phenomena promote the gradual decay due the mechanical restriction, as the surface and internal pore blocking [21].

Initial permeate flux shown in Table II were statistically equal for all operation modes, indicated that chemical cleaning process was successful to recovery the membrane permeability. Steady state permeate flux obtained at the end of the process for diafiltration mode was statistically equal at batch mode and higher than the batch mode with back flushing water pulse, according with the Tukey's test at 5\% significance. 
TABLE II: FLUX DECLINE ANALYSIS AND FouLING RESISTANCE

\begin{tabular}{cccccc}
\hline \hline Ultrafiltration & Initial Permeate & Final steady-state \\
modes operation & flux $\left(\mathrm{kg} / \mathrm{m}^{2} \mathrm{~h}\right)$ & $\begin{array}{c}\text { permeate flux } \\
\left(\mathrm{kg} / \mathrm{m}^{2} \mathrm{~h}\right)\end{array}$ & $\begin{array}{c}\text { Flux } \\
\text { Decay }(\%)\end{array}$ & $\begin{array}{c}\text { Hydraulic } \\
\text { resistance }-R_{M} \\
\left(\mathrm{~m}^{2} / \mathrm{kg}\right) \times 10^{-9}\end{array}$ & $\begin{array}{c}\text { Fouling } \\
\text { resistance }-R_{F} \\
\left(\mathrm{~m}^{2} / \mathrm{kg}\right) \times 10^{-9}\end{array}$ \\
\hline Batch & $93.97 \pm 0.94^{\mathrm{A}}$ & $8.48 \pm 0.58^{\mathrm{AB}}$ & 89.7 & $2.24 \pm 0.02^{\mathrm{A}}$ & $9.43 \pm 0.81^{\mathrm{AB}}$ \\
Diafiltration & $95.43 \pm 1.03^{\mathrm{A}}$ & $9.56 \pm 0.67^{\mathrm{A}}$ & 89.9 & $2.21 \pm 0.02^{\mathrm{A}}$ & $7.92 \pm 0.73^{\mathrm{A}}$ \\
Batch + back flushing & $94.22 \pm 3.92^{\mathrm{A}}$ & $8.02 \pm 0.06^{\mathrm{B}}$ & 90.4 & $2.24 \pm 0.09^{\mathrm{A}}$ & $10.24 \pm 0.32^{\mathrm{B}}$ \\
\hline \hline
\end{tabular}

* means with different letters represent statistically difference according to the Tukey's test $(p<0.05)$

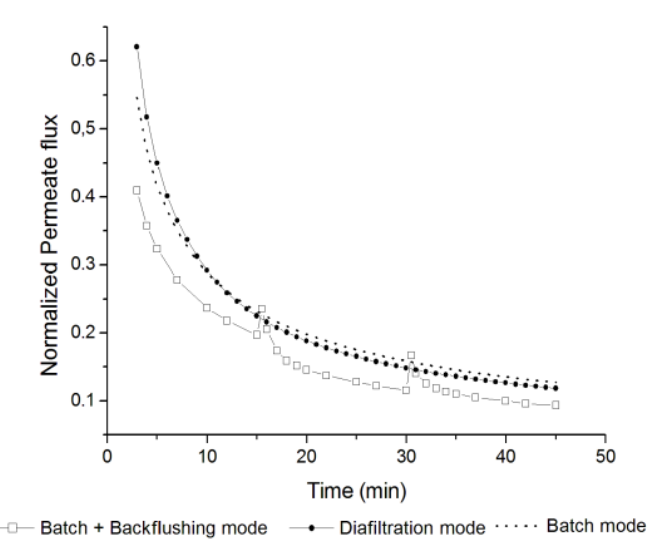

Fig. 4. Permeate flux profile for the operating modes evaluated.

Independent of the ultrafiltration operation mode adopted, the hydraulic resistance RM was nearly the same and the permeate flux reduction was in the order of $90 \%$ (see Table II). This result indicates that physical process is not helpful to avoid the high flux decay due the polarized layer and gel layer precipitation. Same behavior is showed by Sonjui et al. [26], with flux decay in order of $90 \%$, resulting in steady-state permeate flux in order of $20 \mathrm{~L} / \mathrm{m}^{2} \mathrm{~h}$ for treatment of aqueous solution of sericin with ultrafiltration system with flat sheet system and membrane of polysulfone.

The highest final steady-state permeate flux obtained with diafiltration (Table II) can be explained due the addition of water in system during the process, which control the concentration factor, reducing the viscosity. Back flushing water pulse applied in batch mode promoted a small increasing in permeate flux, followed by a sharp decay, as showed in Fig. 4.

As describe by Capar et al. [1], sericin can interact with surface membrane in adsorption uptake, make a monolayer resistance, and is followed by multi-layer protein build-up via intermolecular bonding. In this case, a cleaner membrane was possible to obtain with chemical treatment ( 24 hours of $\mathrm{NaOH}$ $0.1 \mathrm{~mol} / \mathrm{L})$.

TABLE III: SEPARATION/CONCENTRATION OF SERICIN USING MEMBRANE

\begin{tabular}{cccc}
\hline \hline$C F$ & $\begin{array}{c}\text { Sericin concentration in } \\
\text { permeate }(\mathrm{g} / \mathrm{L})\end{array}$ & $\begin{array}{c}\text { Sericin concentration } \\
\text { in retentate }(\mathrm{g} / \mathrm{L})\end{array}$ & $\begin{array}{c}\mathrm{CR} \\
(\%)\end{array}$ \\
\hline 2 & $0.866^{\mathrm{A}}$ & $2.036^{\mathrm{A}}$ & $71.1^{\mathrm{A}}$ \\
3 & $0.950^{\mathrm{A}}$ & $2.002^{\mathrm{A}}$ & $68.3^{\mathrm{A}}$ \\
4 & $1.187^{\mathrm{B}}$ & $2.521^{\mathrm{B}}$ & $60.4^{\mathrm{B}}$ \\
\hline \hline
\end{tabular}

* means with different letters represent statistically difference according to the Tukey's test $(p<0.05)$

The separation process promoted by ultrafiltration allowed the removal of molecular weight below $50 \mathrm{kDa}$ in the permeate stream (Fig. 5a). Retentate showed predominantly molecular weight distribution between $200 \mathrm{kDa}$ and $100 \mathrm{kDa}$ (Fig. 5b), while the permeate stream retains fractions of molecular weight lower than $50 \mathrm{kDa}$.
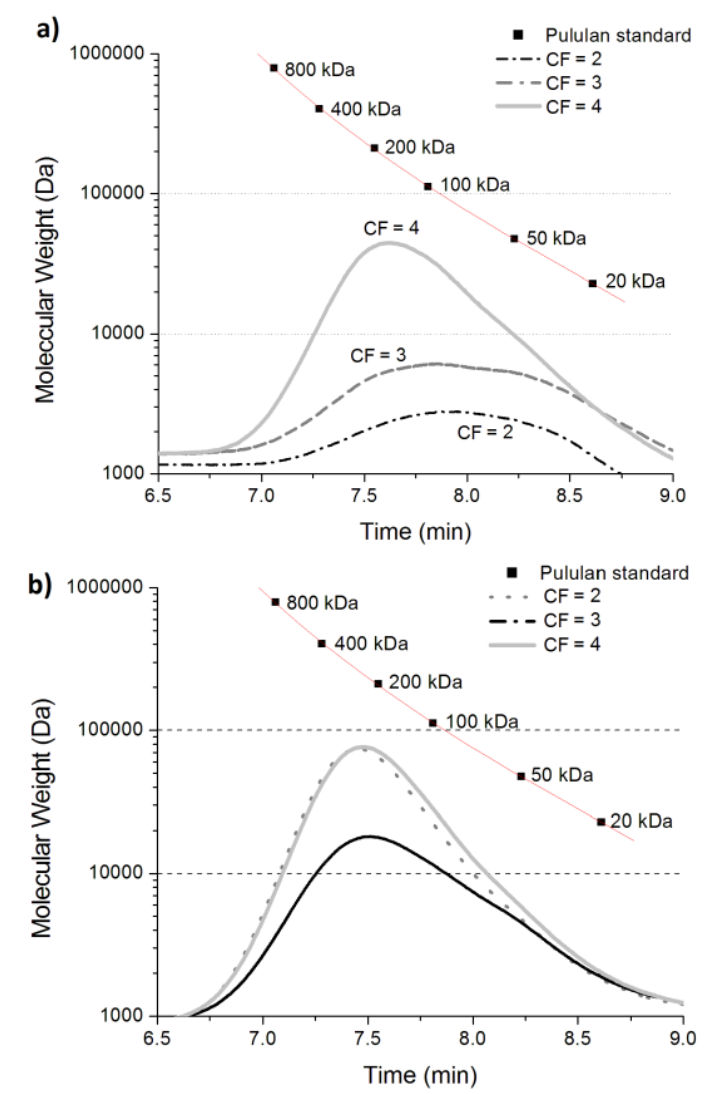

Fig. 5. Molecular weight profile in batch mode. a) permeate stream; b) retentate stream.

However, it was observed sericin permeation with molecular weight above $100 \mathrm{kDa}$ which increases the solvent removal process, or as the increasing of the concentration factor $C F$, as illustrated in Fig. 5a. Table III shows the sericin concentration in retentate and permeate at different values of $C F$, and the coefficient of rejection $C R$ was reduced due to the sericin lose in permeate with long time of operation.

For $F C$ equal 2, same at batch volume reduction of $50 \%$, the sericin retention in ultrafiltration system was $71.1 \%$, while to FC equal 4, i.e. batch volume reduction of $75 \%$, the sericin retention was $60.4 \%$. The results showed in this study (the reduction of the coefficient of rejection with the process time and the profile of molecular weight of sericin in the permeate stream showed in Fig. 5a) suggest that molecules with high molecular weight permeate the membrane after batch volume reduction of $50 \%$.

\section{CONCLUSION}

Sericin extraction with water at $120^{\circ} \mathrm{C}$ obtained yields of $21.99 \pm 0.96 \%$ and fraction with molecular weight between $200 \mathrm{kDa}$ and $100 \mathrm{kDa}$. Carbonate helps the extraction process, but promotes the partial hydrolysis of sericin. 
Ultrafiltration process with membrane of $50 \mathrm{kDa}$ can be applied to sericin recovery with molecular weight above 100 $\mathrm{kDa}$.

Permeate flux presented high decline, above $90 \%$, independent of the operating mode adopted. The steady-state permeate flux obtained varied between 8.02 at $9.56 \mathrm{~kg} / \mathrm{m}^{2} \mathrm{~h}$.

Increasing the concentration factor from 2 to 4 promotes the permeation of sericin molecules of high molecular weight, reducing the rejection coefficient from $71.1 \%$ to $60.4 \%$.

\section{ACKNOWLEDGMENT}

The authors are grateful to FA - Fundação Araucaria, Paraná, Brazil (Project 12401, 14/2009), and FAPESP, São Paulo, Brazil (Project 2011/51824-8), to financial support.

\section{REFERENCES}

[1] Y. Q. Zhang, "Applications of natural silk protein sericin in biomaterials," Biotechnol. Adv., vol. 20, no. 2, pp. 91-100, May, 2002.

[2] G. Capar, S. S. Aygun, and M. R. Gecit, "Treatment of silk production wastewater by membrane process for sericin recovery," J. Membrane Sci., vol. 325, no. 2, pp. 920-931, December, 2008.

[3] P. Vaithanomsat and V. Kitpreechavanich, "Sericin separation from silk degumming wastewater," Sep. Purif. Technol., vol. 59, no. 2, pp. 129-133, February, 2008.

[4] J. Nam and Y. H. Park, "Morphology of regenerated silk fibroin: Effects of freezing temperature, alcohol addition, and molecular weight," J. Appl. Polym. Sci., vol. 81, no. 12, pp. 3008-3021, September, 2000.

[5] G. Freddi, R. Mossotti, and R. Innocenti, "Degumming of silk fabric with several proteases," J. Biotechnol., vol. 106, no. 1, pp. 101-112, December, 2003.

[6] Y. Takasu, H. Yamada, and K. Tsubouchi, "Isolation of three main sericin components from the cocoon of the silkworm, Bombyx mori," Biosci. Biotechnol. Biochem., vol. 66, no. 14, pp. 2715-2718, July, 2002.

[7] J. H. Wu, Z. Wang, and S. Y. Xu, "Enzymatic production of bioactive peptides from sericin recovered from silk industry wastewater," Process Biochem., vol. 43, no. 5, pp. 480-487, May, 2007

[8] M. Sasaki, H. Yamada, and N. Kato, "Consumption of silk protein, sericin elevates intestinal absorption of Zinc, Iron, Magnesium and Calcium in rats," Nutr. Res., vol. 20, no. 10, pp. 1505-1511, October, 2000.

[9] A. Takeuchi, C. Ohtsuki, T. Miyazaki, M. Kamitakahara, S. Ogata, M. Yamazaki, Y. Furutani, H. Kinoshita, and M. Tanihara, "Heterogeneous nucleation of hydroxyapatite on protein: structural effect of silk sericin," J. Royal Soc. Interf., vol. 2, no. 4, pp. 373-378, September, 2005

[10] Y. Cai, D. Mei, T. Jiang, and J. Yao; "Synthesis of oriented hydroxyapatite crystals: Effect of reaction conditions in the presence or absence of silk sericin," Mater. Lett., vol. 64, n. 24, pp. 2676-2678, December, 2010.

[11] M. L. Gimenes, L. Liu, and X. Feng, "Sericin/poly(vinyl alcohol) blend membranes for pervaporation separation of ethanol/water mixtures," $J$. Membrane Sci., vol. 295, no. 1-2, pp. 71-79, May, 2007.

[12] F. R. B. Turbiani, J. Tomadon Jr., F. L. Seixas, and M. L. Gimenes, "Properties and structure of sericin films: Effect of the crosslinking degree," Chem. Eng. T., vol. 24, pp. 1489-1494, 2011.

[13] N. M. Mahmoodi, M. Arami, F. Mazaheri, and S. Rahimi, "Degradation of sericin (degumming) of Persian silk by ultrasound and enzymes as a cleaner and environmentally friendly process," J. Clean. Prod., vol. 18, no. 2, pp. 146-151, January, 2010.

[14] H. Teramoto, T. Kameda, and Y. Tamada, "Preparation of gel film from Bombix mori Silk sericin and its characterization a as wound dressing," Biosci. Biotechnol. Biochem., vol. 72, no. 12, pp. 3189-3196, December,2008.

[15] H. Oh, J. Y. Lee, M. K. Kim, I. C. Um, and K. H. Lee, "Refining hot-water extracted silk sericin by ethanol-induced precipitation," Int. J. Biol. Macromol., vol. 48, no. 1, pp. 32-37, January, 2011.

[16] C. Fabiani, M. Pizzichini, M. Spadoni, and G. Zeddita, "Treatment of waste water from silk degumming processes for protein recovery and water reuse," Desalination, vol. 105, no. 1-2, pp. 1-9, 1996.
[17] M. M. R. Khan, M. Tsukada, Y. Gotoh, H. Morikaha, G. Freddi, and H. Shiozaki, "Physical properties and dyeability of silk fibers degummed with citric acid," Bioresource Technol., vol. 101, no. 21, pp. 8439-8445, November, 2010.

[18] V. R. Silva, F. Hamerski, and A. P. Scheer, "Pretreatment of aqueous pectin solution by cross-flow microfiltration: Analysis of operational parameters, degree of concentration and pectin losses," Int. J. Food Sci. Tech., vol. 46, pp. 1246-1252, June, 2012.

[19] M. M. Bradford, "A rapid and sensitive method for the quantification of microgram quantities of protein utilizing the principle of protein-dye biding," Anal. Biochem., vol. 72, no. 1-2, pp. 248-254, May, 1976.

[20] B. Boissier, F. Lutin, M. Moutounet, and A. Vernhet, "Particles deposition during cross-flow microfiltration of red wines - incidence of the hydrodynamic conditions and the yeast to fine ratio," Chem. Eng. Process., vol. 47, no. 3, pp. 276-286, March, 2008.

[21] A. C. Habert, C. P. Borges, and R. Nobrega, Processos de Separação por Membranas, 1 st ed. Rio de Janeiro, Brazil: e-papers Inc., 2006, ch. 5, pp. 103-138.

[22] K. Haggag, H. El-Sayed, and O. G. Allam, "Degumming of silk using microwave-assisted treatments," Nat. Fibers, vol. 4, no. 3, pp. 1-22, January, 2007.

[23] M. N. Padamwar, A. P. Pawar, A. V. Daithankar, and K. R. Mahadik, "Silk sericin as a moisturizer: an in vivo study," J. Cosmet Dermatol. vol. 4, no. 4, pp. 250-257, December, 2005.

[24] S. Damodaran, K. L. Parkin, and O. R. Fennema, Química de Alimentos de Fennema, 4ed. Porto Alegre, Brazil: Atrmed INC, 2010, ch. 5, pp. 179-262.

[25] V. R. Silva, M. Ribani, M. L. Gimenes, and A. P. Scheer, "High molecular weight of sericin obtained by high temperature and ultrafiltration process," Procedia Eng., vol. 42, pp. 433-441, 2012.

[26] T. Sonjui, C. Noomhorm, and A. Promboon, "Sericin recovery from silk cocoon degumming wastewater by a membrane process," Kasetsart J. Nat. Sci., vol. 43, pp. 538-549, 2009.

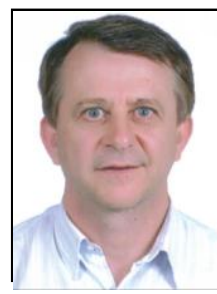

Marcelino Luiz Gimenes graduated in chemical engineering in 1981 from State University of Maringá, and received M. Eng. from State University of Campinas. He obtained a $\mathrm{PhD}$ degree in chemical engineering from Leeds University in England in 1992 , and since 1986 he has been working as a lecturer at State University of Maringá, Brazil.

His main research areas are separation processes including adsorption and membrane separation technologies. He has supervised MSc and $\mathrm{PhD}$ students and published several papers in International journals, National journals and International conferences.

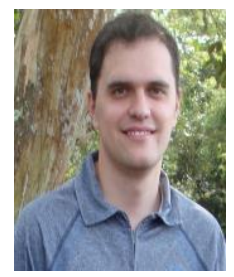

Vitor Renan da Silva graduated in chemical engineering in 2006 from Federal University of Parana. He obtained master degree in food technology from Federal University of Paraná in 2009 and since 2011 has been working in Environmental Department in Curitiba, Brazil. His main research areas are separation process including adsorption, microfiltration and ultrafiltration.

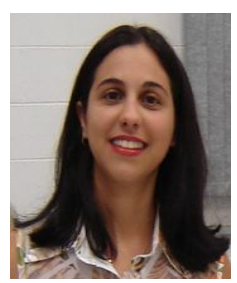

Melissa Gurgel Adeodato Vieira received her B.Eng. in chemical engineering from Federal University of Ceará (UFC/ Brazil), in 2001; M.Eng., in chemical engineering from University of Campinas (UNICAMP) in 2003, Dr. Eng., chemical engineering from University of Campinas in 2006, Pos-doc. from Institute for in Sanitary Engineering, Water Quality and Solid Waste Management (ISWA)- Universität Stuttgart in 2007, Pos-doc. in chemical engineering from University of Campinas in 2008, Pos-doc. in chemical engineering from University of Campinas in 2010.

Melissa has been an assistant professor since 2010 in chemical engineering at UNICAMP/ Brazil. She had participation in 20 research projects and partnership with industry, 12 as coordinator. She published two book chapters, 31 full publications from journals and 57 from national and 
international conferences and specialization courses in environmental engineering.

Prof. Dr. Vieira is a member of Scientific Committee and a reviewer of papers submitted to national and international journals (12) and several scientific technical events. She received two awards, one for academic performance in graduation (Magna cum Lauda) from UFC, in 2001, and another of scientific work in guiding undergraduates UNICAMP-CNPq/PIBIC (2012).

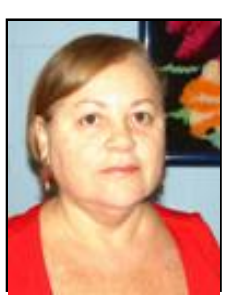

Meuris G. Carlos da Silva received her B.Eng. dgree in chemical engineering from Federal University of Ceará (UFC/Brazil), in 1978; M.Eng., in chemical engineering from University of Campinas (UNICAMP/Brazil), in 1984, Specialist in Safety Engineering, from Catholic University of Campinas, in 1986 and Dr. Eng., mechanical engineering from University of Campinas, in 1994.

Meuris has been a professor since May 2009 in Environmental Engineering, at FEQ / UNICAMP and Associate Professor since September 1999 in Unit Operations at FEQ / UNICAMP and is also Scholarship and Productivity CNPq. She had participation in 33 research projects and partnership with industry, 27 as coordinator. She was coordinator to support 41 projects (infrastructure, organization of events, education, travel aid and scholarships). She published three book chapters, 263 full publications from journals and national and international conferences and taught 18 extension and specialization courses.
Prof. Dr. Silva is a member of Scientific Committee and a reviewer of papers submitted to national and international journals and several scientific technical events. She received four awards, one for best doctoral thesis oriented PPG / FEQ / UNICAMP in 2012 and three of scientific work in guiding undergraduates UNICAMP-CNPq/PIBIC (2005, 2004 and 2003), merits scientific papers presented at the COBEQ-2009 and IC 2005.

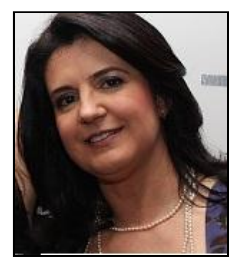

Agnes de Paula Scheer obtained her bachelor degree in chemical engineering from Federal University of Paraná in 1980, master's at science and technology of food from Federal University of Paraná in 1991 and doctorate in chemical engineering from State University of Campinas in 2002. She has been an associate professor since 1988 at Chemical Engineering Department and has supervised master and $\mathrm{PhD}$ students. She has experience in chemical engineering, focusing on operations of Separation, acting on the following subjects: adsorption, emulsions, membrane separation and rheology. Published several papers in International journals, national journals and in annals of events. 